\title{
MERCATORIA
}

Available online http://ojs.uma.ac.id/index.php/mercatoria

\section{Putusan Verstek dalam Hukum Acara Perdata}

\author{
Maswandi * \\ Universitas Medan Area
}

*Corresponding author: E-mail: maswandi@uma.ac.id

\begin{abstract}
Abstrak
Dalam proses persidangan di depan Pengadilan Negeri dikenal adanya putusan akhir sebagai putusan yang berfungsi untuk mengakhiri sengketa atau perkara. Putusan verstek sebagai putusan hakim Pengadilan Negeri dalam perkara perdata adalah salah satu putusan yang masuk dalam golongan putusan akhir. Dalam hukum acara perdata Indonesia mengenai putusan verstek ini diatur dalam pasal 125 H.I.R/149R.Bg. ketidakhadiran para pihak tergugat pada hari sidang yang telah ditentukan adalah salah satu syarat untuk bisa dijatuhkannya putusan verstek oleh hakim Pergadilan Negeri yang memimpin sidang dalam perkara perdata.
\end{abstract}

Kata Kunci: Verstek, putusan verstek

\section{Abstract}

In the trial process in front of the District Court, there is a final decision as a decision that serves to end a dispute or a case. The verdict of verstek as a judge of the District Court in a civil case is one of the decisions that fall within the final decision. In Indonesian civil procedure law regarding this verstek verdict set forth in article 125 H.I.R / 149R.Bg. the absence of the defendant on the appointed day of the hearing is one of the conditions for the judgment of verstek by a district court judge presiding over a trial in a civil case.

Keyword: Verstek, verdict verstek

How to Cite: Maswandi., (2017), Putusan Verstek dalam Hukum Acara Perdata, Mercatoria, 10 (2): 160-179. 


\section{PENDAHULUAN}

Putusan verstek merupakan bagian dari Hukum Acara Perdata di Indonesia. Putusan verstek tidak terlepas hubungannya dengan beracara dan penjatuhan putusan atas perkara yang dipersengketakan yang memberi wewenang kepada Hakim menjatuhkan putusan tanpa hadirnya Tergugat. Putusan verstek berkaitan dengan ketentuan Pasal 125 ayat (1) HIR. ${ }^{1}$

Berdasarkan Pasal 125 ayat (1) HIR, Hakim berwenang menjatuhkan putusan di luar hadir dan atau tanpa hadirnya Tergugat dengan syarat ${ }^{2}$ :

a. Tergugat atau para Tergugat kesemuanya tidak datang pada hari sidang yang telah ditentukan atau tidak mengirimkan jawaban;

b. Tergugat atau para Tergugat tersebut tidak mengirimkan wakil/kuasanya yang sah untuk menghadap atau tidak mengirimkan jawaban;

c. Tergugat atau para Tergugat tersebut telah dipanggil dengan sah dan patut;

d. Gugatan beralasan dan berdasarkan hukum.

Syarat-syarat tersebut di atas harus satu persatu diperiksa dengan seksama, baru apabila benar-benar persyaratan itu kesemuanya terpenuhi, putusan verstek dijatuhkan dengan mengabulkan gugatan, sehingga bisa saja gugatan tidak dapat diterima apabila tidak mempunyai dasar hukum.

Perlu dikemukakan, apabila pada hari yang ditentukan tergugat tidak hadir dan pula ia tidak menyuruh orang lain

\footnotetext{
${ }^{1}$ M Yahya Harahap, Hukum Acara Perdata, (Jakarta: Sinar Grafika, 2006) cet. 4, hlm.381.

2 Varia Peradilan Majalah Hukum Tahun XXIX No. 338 Januari 2014, hlm.51.
}

untuk hadir sebagai wakilnya, padahal ia telah dipanggil dengan patut maka gugatan itu diterima dengan putusan tak hadir (verstek), kecuali kalau ternyata dalam pengadilan negeri bahwa gugatan tersebut melawan hak atau tidak beralasan. ${ }^{3}$

Dalam pedoman teknis Peradilan Perdata Umum, Mahkamah Agung telah memberikan petunjuk penyelesaian seputar permasalahan perkara verstek namun dalam praktiknya masih banyak yang muncul dan perbedaan pelaksanaan. Hal-hal itulah yang masih memerlukan elaborasi hingga menemukan pengertian dan pemahaman yang luas, tepat dan benar tentang putusan verstek. Pengertian yang tepat dan benar dapat diharapkan mendorong sifat tegas dari hakim sehingga asas peradilan sederhana, cepat dan biaya ringan diwujudkan serta untuk memenuhi rasa keadilan masyarakat. ${ }^{4}$

Akan tetapi meskipun proses pemeriksaan berlaku kepada tergugat yang tidak hadir, hakim wajib memerintahkan untuk memanggilnya pada persidangan yang akan datang. Pada persidangan berikutnya terbuka kesempatan mengajukan bantahan apabila tergugat menghadiri persidangan.

Kehadiran tergugat di persidangan adalah hak dari tergugat. Prof. Dr. Sudikno Mertokusumo menyatakan hal tersebut bahwa tidak ada keharusan bagi tergugat untuk datang di persidangan. ${ }^{5}$ Dengan

\footnotetext{
${ }^{3}$ R. Soeroso, Hukum Acara Perdata HIR, Rbg, dan Yurisprudensi, (Jakarta; Sinar Grafika, 2011) cet. 2, hlm. 56

4 Varia Peradilan Majalah Hukum Tahun XXIX No. 338 Januari 2014, hlm. 47

5 Sudikno Mertokusumo, Hukum Acara Perdata, (Yogyakarta; Liberty, 2002), hlm. 101
} 
demikian hak ini boleh diambil atau tidak. Artinya, kehadiran tergugat di persidangan bukanlah suau kewajiban yang bersifat memaksa. Hukum menyerahkan sepenuhnya apakah tergugat mempergunakan hak itu untuk membela kepentingannya. ${ }^{6}$

Ketentuan tersebut dapat dimanfaatkan oleh tergugat untuk menggagalkan penyelesaian perkara. Tergugat dengan itikad buruk dapat tidak memenuhi panggilan oleh pihak pengadilan setiap kali dipanggil untuk menghadiri siding dengan tujuan untuk menghambat pemeriksaan dan penyelesaian perkara.

Dengan pertimbangan akibat buruk yang dapat ditimbulkan itulah maka disediakan proses acara pemeriksaan dengan cara verstek. Melalui cara ini, kehadiran para pihak di persidangan bukan merupakan syarat mutlak sahnya proses pemeriksaan persidangan di pengadilan. Proses pemeriksaan perkara dalam sidang pengadilan dapat tetap berjalan secara sah meskipun tanpa dihadiri oleh salah satu pihak. Namun, bagi pihak yang tidak hadir di persidangan harus menerima konsekuensi bahwa putusan ditetapkan di luar hadirnya pihak tersebut dan mengabulkan gugatan pihak lawan. Penerapan verstek dinilai efektif untuk menciptakan proses beracara yang tertib sesuai dengan asas sederhana, cepat, dan biaya ringan.

Pada sidang pertama, mungkin ada pihak yang tidak hadir dan juga tidak menyuruh wakilnya untuk hadir, padahal sudah dipanggil dengan patut. Pihak yang tidak hadir mungkin Penggugat dan

\footnotetext{
${ }^{6}$ Ibid. Hlm. 79
}

mungkin juga Tergugat. Ketidakhadiran salah satu pihak tersebut menimbulkan masalah dalam pemeriksaan perkara, yaitu perkara itu ditunda atau diteruskan pemeriksaannya dengan konsekuensi yuridis. ${ }^{7}$

Pihak Penggugat yang tidak hadir, maka perkaranya digugurkan dan diperkenankan untuk mengajukan gugatannya sekali lagi setelah ia terlebih dahulu membayar biaya perkara yang baru. Namun jikalau pada hari sidang pertama yang telah ditentukan tergugat tidak hadir ataupun tidak menyuruh wakilnya untuk datang menghadiri persidangan, sedangkan ia telah dipanggil dengan patut, maka gugatan diputuskan dengan verstek. ${ }^{8}$

Putusan verstek adalah menyatakan bahwa tergugat tidak hadir, meskipun ia menurut hukum acara harus datang. Verstek ini hanya dapat dinyatakan, jikalau tergugat tidak hadir pada hari sidang pertama. ${ }^{9}$

Mengenai pengertian verstek, sangat erat kaitannya dengan fungsi beracara di pengadilan, dan hal tersebut tidak terlepas dari penjatuhan putusan atas perkara yang disengketakan, yang memberi wewenang pada hakim menjatuhkan putusan tanpa hadirnya penggugat atau tergugat. Persoalan verstek tidak terlepas dari ketentuan Pasal 124 HIR (Pasal 148 Rbg) dan Pasal 125 HIR (Pasal 149 Rbg).

\footnotetext{
${ }^{7}$ Abdulkadir Muhammad, Hukum Acara Perdata Indonesia, (Bandung: Citra Aditya Bakti, 2000), hlm. 86.

${ }^{8}$ R. Soepomo, Hukum Acara Perdata Pengadilan Negeri, (Jakarta: Pradnya Paradita,1980), hlm. 33

${ }^{9} \mathrm{Ibid}, \mathrm{hlm} .33$.
} 


\section{Pasal 124 HIR. ${ }^{10}$}

Apabila pada hari yang telah ditentukan penggugat tidak hadir dan pula ia tidak menyuruh orang lain untuk hadir sebagai wakilnya, padahal ia telah dipanggil dengan patut, maka gugatannya dinyatakan gugur dan ia dihukum membayar biaya perkara tetapi ia berhak untuk mengajukan gugatan sekali lagi, setelah ia membayar terlebih dahulu biaya tersebut.

Berdasarkan pasal 124 HIR, Hakim berwenang menjatuhkan putusan di luar hadir atau tanpa hadir penggugat dengan syarat ${ }^{11}$ :

a. Bila penggugat tidak hadir pada sidang yang telah ditentukan tanpa alasan yang sah

b. Maka dalam peristiwa seperti itu, hakim berwenang memutus perkara tanpa hadirnya penggugat yang disebut putusan verstek, yang memuat diktum :

1) Membebaskan tergugat dari perkara tersebut,

2) Menghukum penggugat membayar biaya perkara,

c. Terhadap putusan verstek itu, penggugat tidak dapat mengajukan perlawanan (verzet) maupun upaya banding dan kasasi, sehingga terhadap putusan tertutup upaya hukum.

d. Upaya yang dapat dilakukan penggugat adalah mengajukan kembali gugatan itu sebagai perkara baru dengan membayar biaya perkara.

${ }^{10}$ K. Wantjik Saleh, Hukum Acara Perdata, (Jakarta: Ghalia Indonesia,1977) hlm. 29-30.

${ }^{11}$ M. Yahya Harahap, Hukum Acara Perdata, (Jakarta: Sinar Grafika, 2006), hlm. 382.
2. Pasal 125 ayat (1) HIR. ${ }^{12}$

Apabila pada hari yang telah ditentukan, tergugat tidak hadir dan pula ia tidak menyuruh orang lain untuk hadir sebagai wakilnya, padahal ia telah dipanggil dengan patut maka gugatan itu diterima dengan putusan tak hadir (verstek), kecuali kalau ternyata bagi Pengadilan bahwa gugatan tersebut melawan hak atau tidak beralasan.

Menurut M. Yahya Harahap bahwa berdasarkan pasal tersebut di atas, kepada hakim diberi wewenang menjatuhkan putusan diluar atau tanpa hadirnya tergugat, dengan syarat ${ }^{13}$ :

a. Apabila tergugat tidak datang menghadiri sidang pemeriksaan yang ditentukan tanpa alasan yang sah (default without reason)

b. Dalam hal seperti itu, hakim menjatuhkan putusan verstek yang berisi diktum :

1) Mengabulkan gugatan seluruhnya atau sebagian, atau

2) Menyatakan gugatan tidak dapat diterima apabila gugatan tidak mempunyai dasar hukum,

Jika gugatan tidak bersandarkan hukum, yaitu apabila peristiwa-peristiwa sebagai dasar tuntutan tidak membenarkan tuntutan, maka gugatan akan dinyatakan tidak diterima (niet ontvankelijk verklaard). Jika gugatan itu tidak beralasan, yaitu apabila tidak diajukan peristiwa-peristiwa yang membenarkan tuntutan, maka gugatan akan ditolak. Putusan tidak diterima ini

${ }^{12}$ K. Wantjik Saleh, Hukum Acara Perdata, hlm. 30

${ }^{13}$ M. Yahya Harahap, Hukum Acara Perdata, (Jakarta: Sinar Grafika, 2006), hlm. 382. 
bermaksud menolak gugatan di luar pokok perkara, sedang penolakan merupakan putusan setelah dipertimbangkan mengenai pokok perkara. Pada putusan tidak diterima, dikemudian hari penggugat masih dapat mengajukan lagi tuntutannya, tetapi di dalam praktek sekarang ini tidak jarang putusan tidak dapat diterima dimintakan banding, sedang dalam hal ini penolakan tidak terbuka kesempatan untuk mengajukan gugatan tersebut untuk kedua kalinya pada hakim yang sama (ne bis in idem). ${ }^{14}$

Jadi putusan verstek tidak berarti selalu dikabulkannya gugatan penggugat. Pada hakekatnya lembaga verstek itu untuk merealisir asas audi et alteram partem, jadi kepentingan tergugat pun harus diperhatikan, sehingga seharusnya secara ex officio hakim mempelajari isi gugatan. Tetapi di dalam praktek sering gugatan penggugat dikabulkan dalam putusan verstek tanpa mempelajari gugatan lebih dahulu.

Menurut Gemala Dewi bahwa putusan verstek hanya menilai secara formil gugatan dan belum menilai secara materiil kebenaran dalil-dalil gugat. ${ }^{15}$ Disamping itu Abdulkadir Muhammad menyimpulkan bahwa dalam putusan verstek tidak selalu mengalahkan Tergugat, mungkin juga mengalahkan Penggugat. 16

Tujuan utama sistem verstek dalam hukum acara adalah untuk mendorong

${ }^{14}$ Sudikno Mertokusumo, Hukum Acara Perdata Indonesia, (Yogyakarta: Liberty. 1988), hlm. 85.

15 Gemala Dewi, Hukum Acara Perdata Peradilan Agama di Indonesia, (Jakarta: Kencana, 2005), hlm. 152

16 Abdulkadir Muhammad, Hukum Acara Perdata Indonesia, hlm. 88-89. para pihak menaati tata tertib beracara, sehingga proses pemeriksaan penyelesaian perkara terhindar dari anarki atau kesewenangan. Sekiranya undang-undang menentukan bahwa untuk sahnya proses pemeriksaan perkara, mesti dihadiri para pihak, ketentuan yang demikian tentunya dapat dimanfaatkan tergugat dengan itikad buruk untuk menggagalkan penyelesaian perkara. Setiap kali dipanggil menghadiri sidang, tergugat tidak menaatinya dengan maksud untuk menghambat pemeriksaan dan penyelesaian perkara.

Memperhatikan akibat buruk yang mungkin terjadi, yaitu apabila keabsahan proses pemeriksaan digantungkan atas kehadiran para pihak atau tergugat, undang-undang perlu mengantisipasinya melalui acara pemeriksaan verstek. Pemeriksaan dan penyelesaian perkara tidak mutlak digantungkan atas kehadiran tergugat di persidangan. Apabila ketidakhadiran itu tanpa alasan yang sah (unreasonable default), dapat diancam dengan penjatuhan putusan tanpa hadir (verstek). Meskipun penerapan verstek tidak imperatif, namun pelembagaannya dalam hukum acara dianggap sangat efektif menyelesaikan perkara. Misalnya, apabila tergugat tidak hadir pada sidang pertama tanpa alasan yang sah, hakim berwenang langsung menjatuhkan putusan verstek. Atau, apabila pada sidang pertama tidak hadir, kemudian sidang dimundurkan dan tergugat dipanggil menghadiri sidang berikutnya. Hakim masih tetap berwenang menjatuhkan putusan verstek, apabila tergugat tidak hadir karena tanpa alasan yang sah. Memang acara verstek, ini sangat merugikan kepentingan tergugat, karena 
tanpa hadir dan tanpa pembelaan, putusan dijatuhkan. Akan tetapi, kerugian itu wajar ditimpakan kepada tergugat, disebabkan sikap dan perbuatannya yang tidak menaati tata tertib beracara. ${ }^{17}$

Syarat acara verstek terhadap penggugat terdapat dalam bagian pengguguran gugatan berdasarkan Pasal 124 HIR. Sedang yang akan dibicarakan dalam uraian ini adalah verstek terhadap tergugat.

Menurut M. Yahya Harahap ${ }^{18}$, sebagaimana telah diuraikan sebelumnya, secara garis besar syarat sahnya penerapan acara verstek kepada tergugat merujuk kepada ketentuan Pasal 125 HIR ayat (1) atau $78 \mathrm{Rv}$. Bertitik tolak dari pasal tersebut, dapat dikemukakan syaratsyarat sebagai berikut :

1. Tergugat telah dipanggil dengan sah dan patut

2. Tidak hadir tanpa alasan yang sah

3. Tergugat tidak mengajukan eksepsi kompetensi

$$
\text { Pasal } 125 \text { ayat (1) HIR }
$$

menentukan, bahwa untuk putusan

verstek yang mengabulkan gugatan diharuskan adanya syarat-syarat sebagai berikut ${ }^{19}$ :

1. Tergugat atau para tergugat kesemuanya tidak datang pada hari sidang yang telah ditentukan.

2. Ia atau mereka tidak mengirimkan wakil/kuasanya yang sah untuk menghadap

${ }^{17}$ M. Yahya Haharap, Hukum Acara Perdata, (Jakarta: Sinar Grafika, 2006), hlm. 383.

${ }^{18}$ Ibid.

19 Retno Wulan Susanto dan Iskandar Oeripkartawinata, Hukum Acara Perdata dalam Teori dan $P$ raktek, (Bandung: Mandar Maju, 2005), hlm. 26.
3. Ia atau mereka kesemuanya telah dipanggil dengan patut

4. Petitum tidak melawan hak

5. Petitum beralasan

Syarat-syarat tersebut di atas harus satu per satu diperiksa dengan seksama, baru apabila benar-benar persyaratan itu kesemuanya terpenuhi, putusan verstek dijatuhkan dengan mengabulkan gugatan. Apabila syarat 1, 2, dan 3 terpenuhi, akan tetapi petitumnya ternyata melawan hak atau tidak beralasan, maka meskipun mereka diputus dengan verstek, gugat ditolak. Namun apabila syarat 1, 2, dan 3 terpenuhi, akan tetapi ternyata ada kesalahan formil dalam gugatan, misalnya gugatan dianjurkan oleh orang yang tidak berhak, kuasa yang menandatangani surat gugat ternyata tidak memiliki surat kuasa khusus dari pihak penggugat, maka gugatan dinyatakan tidak dapat diterima.

Erfaniah Zuhriah ${ }^{20}$ mengemukakan putusan verstek yang diatur dalam pasal 125 HIR dan 196-197 HIR, pasal 148-153 R.Bg. dan 207-208 R.Bg UU Nomor 20 Tahun 1947 dan SEMA Nomor 9 Tahun 1946. Putusan verstek dapat dijatuhkan apabila telah dipenuhi syarat-syarat, yaitu

1. Tergugat telah dipanggil secara resmi dan patut

2. Tergugat tidak hadir dalam sidang dan tidak mewakilkan kepada orang lain serta tidak ternyata pula bahwa ketidakhadirannya itu karena sesuatu alasan yang sah

20 Erfaniah Zuhriah, Peradilan Agama di Indonesia, (Malang; UIN-Malang Press, 2008), hlm. 275 
3. Tergugat tidak tangkisan/eksepsi kewenangan

4. Penggugat hadir di persidangan, dan

5. Penggugat mohon keputusan

\section{METODE PENELITIAN}

Metode yang dipakai dalam penulisan skripsi adalah dengan cara pengumpulan data dengan penelitian kepustakaan (Library Research) yang dilakukan dengan menelurusuri kepustakaan berdasarkan sumber-sumber bacaan seperti buku-buku, literatur, perundangan-undangan yang berhubungan dengan putusan verstek dalam hukum acara perdata.

\section{HASIL DAN PEMBAHASAN}

Rangkaian proses pemeriksaan persidangan harus berjalan menurut tata cara yang ditentukan oleh peraturan perundang-undangan. Pemeriksaan persidangan pada tingkat pertama di Pengadilan Negeri (PN), tingkat banding di Pengadilan Tinggi (PT), dan tingkat kasasi di Mahkamah Agung (MA) diawali dengan proses pemanggilan (atau biasa disebut dengan panggilan) dan pemberitahuan. Pemanggilan terhadap tergugat harus dilakukan secara patut. Setelah melakukan panggilan, juru sita harus menyerahkan risalah (relaas) panggilan kepada hakim yang akan memeriksa perkara tersebut yang merupakan bukti bahwa tergugat telah dipanggil. ${ }^{21}$ Oleh karena itu, sah atau tidaknya pemanggilan dan pemberitahuan yang dilakukan oleh pihak pengadilan sangat menentukan baik atau buruknya

21 Sudikno Mertokusumo, Hukum Acara Perdata, (Yogyakarta; Liberty, 2002), hlm. 98. proses pemeriksaan persidangan di pengadilan.

\section{Panggilan dalam bahasa Belanda} disebut dengan convocatie atau bijeenroeping. ${ }^{22}$ Sementara itu, pengertian panggilan dalam hukum acara perdata yaitu menyampaikan secara resmi (official) dan patut (properly) kepada pihak-pihak yang terlibat dalam suatu perkara di pengadilan agar memenuhi dan melaksanakan hal-hal yang diminta dan diperintahkan majelis hakim atau pengadilan. ${ }^{23}$ Pemanggilan secara patut adalah bahwa yang bersangkutan telah dipanggil dengan cara pemanggilan menurut undang-undang, dimana pemanggilan dilakukan oleh juru sita dengan membuat berita acara pemanggilan pihak-pihak, yang dilakukan terhadap yang bersangkutan atau wakilnya yang sah, dengan memperhatikan tenggang waktu kecuali dalam hal yang sangat perlu, tidak boleh kurang dari 3 (tiga) hari kerja. ${ }^{24}$

Tujuan pemanggilan yaitu penyampaian pesan atau informasi kepada seseorang agar dia tahu tentang segala sesuatu hal yang hendak dilakukan oleh pihak lawan maupun suatu tindakan yang akan dilakukan pengadilan. ${ }^{25}$ Berdasarkan uraian tersebut, dapat diartikan bahwa ruang lingkup tujuan pemanggilan

${ }^{22}$ Yan Pramadya Puspa, Kamus Hukum, Edisi Lengkap, Bahasa Belanda Indonesia Inggris, (Semarang; Aneka Ilmu,1977), hlm. 254.

${ }^{23}$ M. Yahya Harahap, Hukum Acara Perdata, Tentang Gugatan, Persidangan, Penyitaan, Pembuktian, dan Putusan Pengadilan, (Jakarta; Sinar Grafika, 2005), hlm. 213.

24 Retno Wulan Sutantio dan Iskandar Oeripkartawinata, Hukum Acara Perdata Dalam Teori dan Praktek, (Bandung; Mandar Maju, 2002) hlm. 22. ${ }^{25}$ Op.Cit. hlm. 214 
meliputi juga pemberitahuan. Dengan demikian, oleh karena arti dan cakupan panggilan meliputi pemberitahuan, segala syarat dan tata cara yang ditentukan undang-undang mengenai tindakan hukum pemanggilan, sama dan berlaku sepenuhnya dalam pemberitahuan. ${ }^{26}$

Pemanggilan atau panggilan (convocation, convocatie) dalam arti sempit dan sehari-hari sering diidentikkan hanya terbatas pada perintah menghadiri sidang pada hari yang ditentukan. Akan tetapi, dalam hukum acara perdata, sebagaimana dijelaskan dalam Pasal 388 HIR, pengertian panggilan meliputi makna dan cakupan yang lebih luas, yaitu:27

a. Panggilan sidang pertama kepada penggugat dan tergugat;

b. Panggilan menghadiri sidang lanjutan kepada pihak-pihak atau salah satu pihak apabila sidang yang lalu tidak hadir baik tanpa alasan yang sah atau berdasarkan alasan yang sah;

c. Panggilan terhadap saksi yang diperlukan atas permintaan salah satu pihak berdasarkan Pasal 139 HIR (dalam hal mereka tidak dapat menghadirkan saksi yang penting ke persidangan);

d. Selain dari pada itu, panggilan dalam arti luas, meliputi juga tindakan hukum pemberitahuan atau aanzegging (notification), yaitu:

1) Pemberitahuan putusan Pengadilan Tinggi dan Mahkamah Agung;

2) Pemberitahuan permintaan banding kepada terbanding;

3) Pemberitahuan memori banding dan kontra memori banding;

\footnotetext{
${ }^{26}$ Ibid, hlm. 212

${ }^{27}$ Ibid. hlm. 213
}

4) Pemberitahuan permintaan kasasi dan memori kasasi kepada termohon kasasi;

Panggilan terhadap para pihak untuk menghadiri sidang dilakukan oleh juru sita atau juru sita pengganti di tempat tinggal atau tempat kediaman yang dipanggil atau tempat kedudukannya. ${ }^{28}$

Juru sita adalah petugas yang ditugaskan oleh majelis pengadilan yang mempunyai kewajiban menjalankan pemberitahuan dan semua surat-surat yang lain atau juga menjalankan perintah hakim dengan segala keputusannya. ${ }^{29}$ Prof. Dr. Sudikno Mertokusumo, S.H. dalam bukunya juga menyatakan bahwa pemanggilan dilakukan oleh juru sita yang menyerahkan surat panggilan (exploit) beserta salinan gugat kepada tergugat pribadi di tempat tinggalnya. ${ }^{30}$ Hal ini sebagaimana diatur dalam Pasal 388 ayat (1) jo. Pasal 390 ayat (1) HIR yang berbunyi sebagai berikut:

Pasal 388 ayat (1)

Semua juru sita dan suruhan yang dipekerjakan pada majelis pengadilan dan pegawai umum pemerintah mempunyai hak yang sama dan diwajibkan untuk menjalankan panggilan, pemberitahuan, dan semua surat juru sita yang lain, juga menjalankan perintah hakim dan keputusan-keputusan.

Pasal 390 ayat (1)

${ }^{28}$ Keputusan Ketua Mahkamah Agung Republik Indonesia Nomor : KMA/032/SK/IV/2006 angka ke-2 huruf $\mathrm{C}$.

${ }^{29}$ Yan Pramadya Puspa, Kamus Hukum, Edisi Lengkap, Bahasa Belanda Indonesia Inggris, (Semarang; Aneka Ilmu, 1977), hlm. 254.

${ }^{30}$ Sudikno Mertokusumo, Hukum Acara Perdata, (Yogyakarta; Liberty, 2002), hlm. 97. 
Tiap-tiap surat juru sita, kecuali yang akan disebutkan di bawah ini, harus disampaikan pada orang yang bersangkutan sendiri di tempat diamnya atau tempat tinggalnya dan jika tidak dijumpai di situ, kepada kepala desanya atau lurah bangsa Tionghoa yang diwajibkan dengan segera memberitahukan surat juru sita itu pada orang itu sendiri, dalam hal terakhir ini tidak perlu pernyataan menurut hukum.

Berdasarkan ketentuan yang diatur dalam pasal-pasal tersebut, dapat ditarik kesimpulan sebagai berikut:

a. Pemanggilan dilakukan oleh juru sita sesuai dengan kewenangan relatif yang dimilikinya.

b. Jika orang yang hendak dipanggil berada di luar yuridiksi relatif yang dimilikinya, pemanggilan dilakukan berdasarkan ketentuan Pasal 5 Rv, yaitu mendelegasikan pemanggilan kepada juru sita yang berwenang di wilayah hukum tersebut. ${ }^{31}$ Kewenangan atau yuridiksi relatif juru sita mengikuti kewenangan relatif Pengadilan Negeri dimana ia terdaftar sebagai juru sita.

Pasal $5 \mathrm{Rv}$ tersebut berbunyi sebagai berikut:

Jika tergugat bertempat tinggal di luar wilayah kekuasaan hakim yang menerima gugatan atau segera dalam hal sepeti diuraikan di atas atau atas pilihan penggugat atau atas permohonan pengacaranya dengan surat kepada hakim di tempat tinggal tergugat yang kemudian akan

\footnotetext{
${ }^{31}$ M. Yahya Harahap, Hukum Acara Perdata, Tentang Gugatan, Persidangan, Penyitaan, Pembuktian, dan Putusan Pengadilan, (Jakarta; Sinar Grafika, 2005), hlm. 219.
}

memberitahukannya dengan perantara juru sita yang ditunjuknya, jika tergugat bertempat tinggal di dalam keresidenan tempat akan diadakan sidang majelis, dan jika tidak tinggal disitu ia akan mengirim surat kepada asisten residen yang mempunyai wilayah tempat tinggal tergugat.

Panggilan yang sah dan resmi harus dilakukan oleh juru sita. Pelaksanaan panggilan oleh juru sita merupakan salah satu syarat agar panggilan dapat dinyatakan sebagai panggilan yang sah dan resmi.

Pasal 121 ayat (1) HIR berbunyi sebagai berikut:

Sesudah surat gugat yang dimasukkan itu atau catatan yang diperbuat itu dituliskan oleh panitera dalam daftar yang disediakan untuk itu, maka ketua menentukan hari dan jamnya perkara itu akan diperiksa di muka pengadilan negeri, dan ia memerintahkan memanggil kedua belah pihak supaya hadir pada waktu itu, disertai oleh saksi-saksi yang dikehendakinya untuk diperiksa, dan dengan membawa segala surat-surat keterangan yang hendak dipergunakannya.

Berdasarkan Pasal 121 ayat (1) HIR tersebut, kewenangan yang dimiliki juru sita ini diperoleh melalui perintah ketua majelis hakim yang dituangkan dalam penetapan hari sidang atau penetapan pemberitahuan. Kewenangan yang dimiliki juru sita dalam melakukan pemanggilan terbatas pada wilayah kewenangan relatif pengadilan tempat ia bertugas. Oleh karena itu, apabila orang yang hendak dipanggil berada di luar kewenangan relatif juru sita, maka juru sita tersebut harus mendelegasikan kewenangannya itu 
kepada juru sita pengadilan di mana orang yang hendak dipanggil berada.

Pengertian

pemanggilan adalah

pendelegasian

melimpahkan pelaksanaan pemanggilan kepada juru sita pada pengadilan negeri yang lain. ${ }^{32}$ Misalnya tergugat bertempat tinggal di wilayah Bogor, sedangkan perkaranya disidangkan di Pengadilan Negeri Jakarta Selatan, maka juru sita Pengadilan Negeri Jakarta Selatan yang hendak melakukan pemanggilan harus mendelegasikan wewenangnya tersebut kepada juru sita Pengadilan Negeri Bogor.

Dalam hal seperti ini, juru sita Pengadilan Negeri Jakarta Selatan tidak berwenang menyampaikan panggilan karena orang yang hendak dipanggil berada dalam kewenangan relatif Pengadilan Negeri Bogor. Dengan demikian, yang berwenang melakukan panggilan adalah juru sita Pengadilan Negeri Bogor.

Ketentuan yang mengatur mengenai pendelegasian wewenang untuk melakukan pemanggilan diatur dalam Pasal 5 Rv. Penerapan yang diatur dalam pasal tersebut adalah sebagai berikut:

a. Orang yang hendak dipanggil berada di luar wilayah hukum atau kewenangan relatif pengadilan negeri tempat juru sita bertugas.

b. Pemanggilan dilaksanakan oleh juru sita pengadilan negeri yang meliputi wilayah hukum tempat tinggal orang yang hendak dipanggil.

c. Ketua pengadilan negeri yang bersangkutan meminta bantuan kepada ketua pengadilan negeri yang membawahi wilayah hukum tempat

\footnotetext{
${ }^{32}$ Ibid. hlm. 225
}

tinggal tergugat untuk memerintahkan juru sita pengadilan negeri tersebut menyampaikan pemanggilan.

d. Ketua pengadilan yang dimintai bantuan mengeluarkan perintah pemanggilan kepada juru sita berdasarkan permintaan bantuan yang dimaksud.

e. Segera setelah itu, menyampaikan langsung kepada ketua pengadilan negeri yang melimpahkan tentang pelaksanaan pemanggilan yang dilakukan.

Berdasarkan Pasal 390 ayat (1) HIR dan Pasal 2 ayat (3) Rv, panggilan harus dilakukan dalam bentuk surat tertulis. Surat tertulis ini lazim disebut dengan surat panggilan atau relaas (bericht, report) panggilan maupun berita acara panggilan. ${ }^{33}$ Panggilan yang disampaikan dalam bentuk lisan tidak dibenarkan karena sulit untuk membuktikan keabsahannya sehingga dapat merugikan pihak yang dipanggil. Oleh karena itu panggilan dalam bentuk lisan tidak sah menurut hukum. ${ }^{34}$ Ruang lingkup pengertian pemanggilan dalam bentuk tertulis diatur dalam Pasal 2 ayat (3) Rv. Pasal ini mengatur bahwa pemanggilan dalam bentuk tertulis berupa telegram dan surat tercatat dapat dibenarkan dan dianggap sebagai panggilan atau pemberitahuan yang patut (properly). Bunyi pasal tersebut yaitu :

"Pemberitahuan dengan surat tercatat antara lain berlaku sebagai pemberitahuan yang patut.

\footnotetext{
${ }^{33}$ Subakti, Hukum Acara Perdata, (Jakarta; Bina Cipta, 1977), hlm. 5

${ }^{34}$ Op Cit. hlm. 384
} 
Pemberitahuan dilaksanakan atas biaya yang berkepentingan. Pegawai negeri yang menerima pemberitahuan tidak berkewajiban melaporkan atau memberi penjelasan lebih lanjut tentang hal itu selama yang berkepentingan belum mengganti biaya nya."

Ketentuan yang mengatur isi surat panggilan diatur dalam Pasal 121 ayat (1) dan (2) HIR serta Pasal 1 Rv. Bunyi pasal tersebut yaitu sebagai berikut:

Pasal 121 ayat (1) HIR

Sesudah surat gugat yang dimasukkan itu atau catatan yang diperbuat itu dituliskan oleh panitera dalam daftar yang disediakan untuk itu, maka ketua menentukan hari dan jamnya perkara itu akan diperiksa di muka pengadilan negeri, dan ia memerintahkan memanggil kedua belah pihak supaya hadir pada waktu itu, disertai oleh saksi-saksi yang dikehendakinya untuk diperiksa, dan dengan membawa segala surat-surat keterangan yang hendak dipergunakannya.

Pasal 121 ayat (2) HIR

Ketika memanggil tergugat, maka beserta itu diserahkan juga sehelai salinan surat gugat dengan memberitahukan bahwa ia, kalau mau, dapa menjawab surat gugat itu dengan surat.

Pasal $1 \mathrm{Rv}$

Tiap-tiap proses perkara perdata sepanjang tidak dikecualikan secara khusus, dimulai dengan suatu pemberitahuan gugatan yang dilakukan oleh seorang juru sita yang mempunyai wewenang di tempat pemberitahuan itu, wajib menyampaikan turunan surat pemberitahuan itu kepada orang yang digugat itu. Turunan itu berlaku bagi orang yang menerimanya sebagai surat gugatan asli.

Berdasarkan bunyi ketentuan tersebut dapat ditarik kesimpulan bahwa hal-hal yang harus dicantumkan dalam isi surat panggilan, yaitu:

a. Nama yang dipanggil;

b. Hari dan jam serta tempat sidang;

c. Membawa saksi-saksi yang diperlukan;

d. Membawa segala surat-surat yang hendak digunakan, dan

e. Penegasan dapat menjawab gugatan dengan surat;

f. Melampiri surat panggilan dengan salinan surat gugatan, surat panggilan kepada tergugat untuk sidang pertama harus menyebutkan penyerahan sehelai salinan surat gugatan dan pemberitahuan kepada pihak tergugat, bahwa ia boleh mengajukan jawaban tertulis yang diajukan dalam sidang ${ }^{35}$

g. Salinan tersebut dianggap gugatan asli

Hal-hal yang menjadi isi surat panggilan tersebut bersifat kumulatif dan imperatif. Artinya, lima hal yang menjadi isi surat panggilan tersebut harus terpenuhi semuanya. Apabila salah satunya saja tidak terpenuhi maka surat panggilan tersebut menjadi cacat hukum dan dianggap tidak sah. Akan tetapi, dalam

35 Keputusan Ketua Mahkamah Agung Republik Indonesia Nomor : KMA/032/SK/IV/2006 angka ke-2 huruf $\mathrm{C}$. 
rangka menjalankan sistem peradilan yang cepat, sederhana, dan biaya ringan maka kesalahan atau kelalaian dalam mencantumkan isi selain mengenai nama pihak yang dipanggil, hari, dan tempat persidangan masih dapat diberikan ditoleransi. Dengan demikian, kesalahan atau kelalaian seperti itu tidak mengakibatkan panggilan tidak sah.

Selain itu, surat panggilan juga harus memenuhi beberapa persyaratan agar dapat dikatakan sebagai surat panggilan yang sah secara otentik. Persyaratan-persyaratan yang harus dipenuhi tersebut yaitu:

a. Ditandatangani oleh juru sita

Apabila sudah ditandangani dengan sendirinya menurut hukum sah sebagai akta otentik yang dibuat oleh pejabat juru sita. ${ }^{36}$

Akta otentik ini hanya dapat digugurkan jika ada suatu putusan pidana pemalsuan surat yang telah berkekuatan hukum tetap dari pengadilan yang menyatakan isi atau tanda tangan yang tercantum di dalamnya adalah palsu.

b. Berisi keterangan yang diulis tangan juru sita yang menjelaskan panggilan telah disampikan di tempat tinggal yang bersangkutan secara in person, atau kepada keluarga, atau kepada kepala desa, atau lurah disertai dengan tanda tangan orang yang menerima panggilan tersebut.

Tata cara pemanggilan menurut menurut hukum diatur dalam Pasal 390

\footnotetext{
${ }^{36}$ M. Yahya Harahap, Hukum Acara Perdata Tentang Gugatan, Persidangan, Penyitaan, Pembuktian, dan Putusan Pengadilan, (Jakarta; Sinar Grafika, 2005), hlm. 227.
}

ayat (1) dan (2) dan (3) HIR ${ }^{37}$, Pasal 1, Pasal 6, angka ke-7 dan ke-8, serta Pasal 7 Rv. ${ }^{38}$ Pasal-pasal tersebut mengklasifikasi tata cara pemanggilan berdasarkan diketahui atau tidak diketahuinya tempat tinggal tergugat atau orang yang dipanggil, pemanggilan tergugat yang berada di luar negeri, dan pemanggilan terhadap yang telah meninggal dunia.

Ruang lingkup pengertian tempat tinggal seseorang meliputi ${ }^{39}$ :

a. Tempat kediaman, atau

b. Tempat alamat tertentu, atau

c. Tempat kediaman sebenarnya

Yang dimaksud kediaman sebenarnya atau sebenarnya berdiam adalah tempat secara nyata tinggal. ${ }^{40}$ Yang sah dan resmi dijadikan sumber menentukan tempat tinggal tergugat dari beberapa jenis akta atau dokumen. Yang terpenting diantaranya: 41

1) Berdasarkan KTP,

2) Kartu rumah tangga atau kartu keluarga,

3) Surat pajak, dan

4) Anggaran dasar perseroan.

Ketentuan yang mengatur jarak waktu antara pemanggilan dengan hari

37 M. Karjadi, Reglemen Indonesia yang Diperbaharui, S 1941 No. 44, RIB (HIR), (Bogor; Politeia, 1991), hlm. 95

${ }^{38}$ Engelbrecht, Himpunan Peraturan Perundang-Undangan Menurut Sistem Engelbrecht, Buku I, Tata Negara, Perdata, Dagang, Pidana, (Jakarta; Ichtiar Baru Van Hoeve, 2007), hlm 671 dan 673.

${ }^{39}$ M. Yahya Harahap, Hukum Acara Perdata,

Tentang Gugatan, Persidangan, Penyitaan, Pembuktian, dan Putusan Pengadilan, (Jakarta; Sinar Grafika, 2005), hlm. 192.

${ }^{40}$ Ibid. hlm. 193

${ }^{41}$ Ibid. 
sidang yaitu Pasal $122 \mathrm{HIR}^{42}$ dan Pasal 10 $\mathrm{Rv}^{43}$. Menurut ketentuan tersebut, hal-hal yang mempengaruhi dalam menentukan jarak waktu antara pemanggilan dengan hari sidang yaitu:

a. Faktor jarak antara tempat tinggal tergugat dengan gedung tempat sidang dilangsungkan. Pasal $10 \mathrm{Rv}$ mengatur hal tersebut sebagai berikut:

1) Apabila jarak antara tempat tinggal tergugat dengan gedung pengadilan negeri tempat sidang tidak jauh, jarak waktu antara pemanggilan dengan hari sidang adalah 8 (delapan) hari.

2) Apabila jarak waktu antara tempat tinggal tergugat dengan gedung pengadilan negeri tempat sidang agak jauh, jarak waktu antara pemanggilan dengan hari sidang adalah 14 (empat belas) hari.

3) Apabila jarak antara tempat tinggal tergugat dengan gedung pengadilan negeri tempat sidang jauh, jarak waktu antara pemanggilan dengan hari sidang adalah 20 (dua puluh) hari.

Mengenai definisi tidak jauh, agak jauh, dan jauh, ketentuan Pasal 10 Rv tidak menjelaskannya lebih jauh.

b. Jarak waktu pemanggilan dengan hari sidang dalam keadaan yang mendesak diatur dalam Pasal 122 HIR. Pasal tersebut menentukan bahwa jarak waktu pemanggilan dalam keadaan

${ }^{42}$ M. Karjadi, Reglemen Indonesia yang Diperbaharui, S 1941 No. 44, RIB (HIR), (Bogor; Politeia, 1991), hlm. 35

43 Engelbrecht, Himpunan Peraturan Perundang-Undangan Menurut Sistem Engelbrecht, Buku I, Tata Negara, Perdata, Dagang, Pidana, (Jakarta; Ichtiar Baru Van Hoeve, 2007), hlm 674. mendesak dapat dipersingkat dengan syarat tidak boleh kurang dari 3 (tiga) hari. Definisi keadaan mendesak dalam hal ini yaitu tergugat dalam keadaan perlu benar tidak dijelaskan oleh undang-undang. ${ }^{44}$ Penilaian mengenai keadaan yang mendesak sepenuhnya berdasarkan pertimbangan hakim dengan didasari alasan yang objektif.

c. Jarak waktu pemanggilan dengan hari sidang terhadap orang yang berada di luar negeri. Prinsipnya didasarkan pada perkiraan yang wajar dengan mempertimbangkn faktor jarak negara tempat tinggal tergugat dengan Indonesia pada satu segi dan jarak tempat tinggal tergugat dengan Konsulat Jenderal Republik Indonesia serta faktor birokrasi yang harus ditempuh dalam penyampaian panggilan. ${ }^{45}$

d. Jarak waktu pemanggilan dengan hari sidang apabila tergugat terdiri dari beberapa orang. Penentuan jarak waktu pemanggilan dengan hari sidang dalam hal tergugat terdiri dari beberapa orang tidak diatur dalam HIR, tetapi diatur dalam Pasal 14 Rv. Bunyi pasal tersebut yaitu sebagai berikut:

"Jika beberapa orang karena gugatan yang sama ditetapkan untuk jangka waktu yang berlainan, maka semua akan ditetapkan untuk datang menghadap pada waktu yang ditentukan untuk yang bertempat tinggal terjauh."

${ }^{44}$ M. Yahya Harahap, Hukum Acara Perdata,

Tentang Gugatan, Persidangan, Penyitaan, Pembuktian, dan Putusan Pengadilan, (Jakarta; Sinar Grafika, 2005), hlm. 192.

${ }^{45}$ Ibid. hlm. 192. 
Mengenai bentuk putusan verstek yang dapat dijatukan, diatur dalam Pasal 125 ayat (1) HIR, Pasal 149 RBg, dan Pasal $78 \mathrm{Rv}{ }^{46}$

Pasal 125 ayat (1) HIR berbunyi:

"Jika tergugat tidak datang pada hari perkara itu diperiksa, atau tidak pula menyuruhorang lain menghadap mewakilinya, meskipun ia dipanggil dengan patut maka gugatan itu diterima dengan tidak hadir (verstek), kecuali kalau nyata kepada PN bahwa pendakwaan itu melawan hak atau tidak beralasan" 47

Memperhatikan kalimat terakhir pasal di atas, bentuk putusan verstek yang dijatuhkan pengadilan terdiri dari :

A. Putusan Verstek yang Berisi Mengabulkan Gugatan Penggugat

Bentuk putusan verstek yang pertama, mengabulkan gugatan penggugat. Apabila hakim hendak menerapkan acara verstek , pada prinsipnya, putusan yang harus dijatuhkan mengabulkan gugatan penggugat. 48

Bertitik tolak dari prinsip tersebut, tanggung jawab hakim dalam penerapan acara verstek adalah berat. Tanpa melalui proses pemeriksaan yang luas dan mendalam terhadap fakta-fakta yang melekat dalam sengketa, hakim mengabulkan gugatan, semata-mata berdasarkan surat gugatan yang diajukan penggugat. Berarti putusan diambil tanpa perlawanan dan bantahan dari pihak tergugat.

${ }^{46}$ M. Yahya Harahap, Hukum Acara Perdata, (Jakarta: Sinar Grafika, 2006), hlm. 397.

47 Soesilo, RIB/HIR dengan Penjelasan, (Bogor; Politeia, 1985), hlm. 83

${ }^{48}$ M. Yahya Harahap, Hukum Acara Perdata, (Jakarta: Sinar Grafika, 2006), hlm. 397.
Oleh karena itu, tidak dianjurkan untuk menerapkan acara verstek secara tidak bertanggung jawab. Penerapannya, dilakukan sebagai langkah akhir (last resort). Paling tidak kemangkiran tergugat menghadiri sidang sudah sampai pada batas titik toleransi, sehingga cukup beralasan menerapkannya.

Putusan verstek merupakan putusan yang dijatuhkan secara sepihak tanpa adanya bantahan atau perlawanan sehingga hakim hanya akan memeriksa isi gugatan berdasarkan suatu proses pemeriksaan yang sangat sederhana, bahkan jika kita melihat rumusan Pasal 125 ayat (1) HIR, maka cenderung sangat singkat dan sederhana tanpa adanya proses penundaan sidang untuk sekedar merumuskan putusan yang akan dijatuhkan. ${ }^{49}$ Berdasarkan Pasal 125 ayat (1) HIR jika gugatan tersebut tidak melawan hak dan memiliki alasan, maka gugatan tersebut diterima, kalimat undang-undang tersebut seakan memberikan pesan kepada hakim untuk mengabulkan seluruh gugatan penggugat seandainya gugatan tersebut tidak melawan hak dan memiliki alasan yang dapat dibenarkan oleh hukum.

Pada prinsipnya ada beberapa syarat agar suatu gugatan bisa dikabulkan untuk seluruhnya, antara lain: 50

1. Gugatan yang diajukan tidak memiliki cacat formil maupun cacat materiil;

2. Gugatan mengandung posita dan petitum yang saling bersesuaian, artinya dalil-dalil yang terdapat dalam

49 D.Y.Witanto, SH. Hukum Acara Perdata Tentang Ketidakhadiran Para Pihak Dalam Proses Berperkara. (Bandung; Mandar Maju, 2013. hlm. 132 ${ }^{50}$ Ibid, hlm. 132 
gugatan mendukung terhadap tuntutan yang dimohonkan;

3. Petitum yang dimohonkan tidak melebihi dari apa yang didalilkan;

4. Apa yang didalilkan di dalam gugatan dapat dibuktikan dengan alat-alat bukti yang sah.

Hakim tidak akan kesulitan untuk menilai tiga syarat yang pertama, karena cukup pemeriksaannya dengan cara membaca gugatan, namun untuk menilai syarat yang keempat dimana suatu dalil gugatan dapat dibuktikan oleh penggugat berdasarkan alat-alat bukti yang sah tentunya tidak dapat begitu saja disimpulkan oleh hakim tanpa melalui proses pembuktian sebagaimana diatur dalam hukum acara perdata. Lalu apakah maksud dalam Pasal 125 ayat (1) HIR yang menyebutkan bahwa gugatan yang dapat diterima itu adalah gugatan yang tidak melawan hak dan memiliki alasan itu sebagai bentuk pengertian dari gugatan yang dapat dibuktikan? Oleh karena itu kita harus menganalisis persoalan tersebut diantara dua kelompok yang memperdebatkan tentang bisa tidaknya proses pembuktian dilakukan dalam acara verstek, maka sebagaimana pernah disampaikan pada pembahasan yang lalu, bahwa penulis lebih setuju untuk tetap dilakukan proses pembuktian, namun hanya menyangkut mengenai pembuktian surat-surat saja yang pelaksanaannya dilakukan bersamaan dengan sidang pada waktu putusan verstek itu diucapkan, pendapat tersebut didasarkan pada ketentuan yang diatur dalam Pasal 79 Rv. ${ }^{51}$
Jika berdasarkan bukti-bukti surat yang diajukan ternyata penggugat dapat membuktikan dalil-dalil yang disebutkan dalam posita gugatan, maka hakim dapat menjatuhkan putusan verstek yang berisi mengabulkan gugatan. ${ }^{52}$ Namun perlu kiranya diperhatikan bahwa meskipun penggugat telah mampu mengajukan bukti-bukti untuk meneguhkan dalil-dalil gugatannya, hakim tetap harus sangat berhati-hati dalam menjatuhkan putusan verstek karena putusan yang akan dijatuhkan semata-mata hanya dibangun berdasarkan dalil dan pembuktian sepihak, sehingga jika tidak dibangun kehati-hatian dalam melihat dan mempertimbangkan semua dalil-dalil dan bukti-bukti yang diajukan, maka tidak menutup kemungkinan akan menimbulkan kerugian pihak tergugat atau bahkan pihak lain di luar para pihak yang tercantum dalam perkara tersebut.

Ada kecendrungan pendapat bahwa jika materi gugatan tidak melawan hak dan memiliki alasan, maka hakim tidak memiliki pilihan lain, selain mengabulkan gugatan tersebut untuk seluruhnya, pendapat tersebut dilatarbelakangi dari penafsiran Pasal 125 ayat (1) HIR yang mengatakan gugatan diterima dengan verstek. ${ }^{53}$ Namun apakah memang harus selalu demikian dan sama sekali tertutup kemungkinan bagi hakim untuk mengabulkan hanya sebagian saja dari seluruh tuntutan yang diajukan oleh penggugat? Di atas telah sedikit disinggung bahwa di dalam petitum gugatan yang diajukan penggugat tidak

${ }^{52}$ Ibid. Hlm. 133

${ }^{53}$ M. Yahya Harahap. Op Cit. (Jakarta; Sinar Grafika, 2006). hlm. 396. 
selalu menyangkut mengenai pokok tuntutan karena adakalanya tuntutan itu bersifat pelengkap, misalnya tuntutan mengenai sita jaminan, tuntutan mengenai uang paksa (dwangsom) atau tuntutan mengenai diktum yang dapat dijalankan lebih dulu (uitvoerbaar bij voorraad).

Kalau kita cermati bunyi Pasal 125 ayat (1) HIR, maka sebenarnya tidak disebutkan bahwa gugatan itu harus dikabulkan seluruhnya dengan verstek, sehingga dengan mengabulkan sebagian tuntutan saja telah mengandung pengertian bahwa gugatan tersebut dikabulkan. Disamping mengabulkan gugatan untuk sebagian karena beberapa petitum memang tidak mungkin untuk dikabulkan, bisa saja sebenarnya hakim mengabulkan sebagian tuntutan pokok penggugat, misalnya jika yang dituntut adalah 2 (dua) bidang tanah namun yang mampu dibuktikan hanyalah 1 (satu) bidang tanah, maka tidak menutup kemungkinan bagi hakim untuk mengabulkan hanya 1 (satu) bidang tanah saja yang nyata-nyata mampu dibuktikan oleh penggugat.

Kewenangan hakim untuk mengabulkan sebagian saja dari tuntutan penggugat dalam beberapa hal juga bisa menjadi sarana bagi hakim untuk dapat melihat dan mempelajari gugatan secara maksimal sehingga jika berdasarkan pengamatan dan penelaahan terhadap bukti-bukti surat yang diajukan oleh penggugat ternyata tidak mampu dibuktikan semua dalil yang ada di dalam gugatan, maka hakim lebih leluasa untuk menyaring segala tuntutan yang dimintakan kepada hakim di dalam gugatan penggugat. Terdapat beberapa alasan yang dapat digunakan oleh hakim untuk menjatuhkan putusan verstek dengan hanya mengabulkan sebagian tuntutan saja, antara lain sebagai berikut: 54

1. Untuk sedapat mungkin menghindari agar putusan tersebut tidak non executable ;

2. Untuk sedapat mungkin agar tuntutan yang dikabulkan itu kemudian hari tidak mengandung benturan dengan kepentingan orang lain yang tidak turut menjadi pihak dalam perkara tersebut ;

3. Untuk sedapat mungkin menghindari terjadinya kekeliruan di dalam putusan yang ditimbulkan oleh larangan bagi hakim untuk menyaring petitum-petitum gugatan yang dianggap tidak sesuai dengan pembuktian yang diajukan ;

Ada beberapa bentuk putusan yang isinya mengabulkan gugatan penggugat untuk sebagian, antara lain: ${ }^{55}$

1. Putusan mengabulkan sebagian dari item petitum yang dimohonkan penggugat di dalam gugatannya ;

2. Putusan mengabulkan sebagian nilai ganti rugi yang dimohonkan oleh penggugat ;

3. Putusan mengabulkan sebagian jumlah objek sengketa yang dimohonkan;

4. Putusan mengabulkan sebagian dari jumlah dwangsom yang dimintakan terkait dengan permohonan yang mengandung eksekusi riil ;

5. Putusan mengabulkan sebagian dari nilai bunga yang dimohonkan oleh penggugat dalam gugatan wanprestasi.

\footnotetext{
${ }^{54}$ D.Y. Witanto. Op Cit. hlm. 135

${ }^{55}$ Ibid. hlm. 135
} 
Menurut pendapat ini, memeriksa dan memutus suatu perkara bukanlah sekadar menyelesaikan sengketa demi kepentingan penyelesaian itu sendiri. Penyelesaian perkara, tidak berpatokan pada kepentingan hakim (the interest of the judge) atau untuk kepentingan penggugat atau tergugat saja. Akan tetapi, titik sentralnya adalah kepentingan keadilan (for the interest of the justice). ${ }^{56}$

Bertitik tolak dari penjelasan di atas, sangat objektif dan rasional menerapkan pengabulan sebagian gugatan melalui putusan verstek. Akan tetapi, sepanjang petitum gugatan benar-benar sesuai dengan dalil gugatan, serta dalil gugatannya mempunyai landasan hukum yang kuat, objektif dan rasional; dapat dibenarkan mengabulkan seluruh gugatan. Sebaliknya, apabila cukup dasar alasan yang dapat dikabulkan, hanya untuk sebagian, hakim bebas dan berwenang mengabulkan sebagian saja. ${ }^{57}$

\section{B. Putusan Verstek yang Berisi Penolakan Gugatan \\ Walaupun dalam acara verstek} hakim melakukan pemeriksaan secara sepihak, namun bukan berarti bahwa gugatan tersebut pasti harus dikabulkan. Putusan verstek merupakan bagian dari resiko yang harus ditanggung oleh pihak tergugat/para tergugat atas kelalaiannya untuk menghadiri panggilan sidang, namun bukan berarti bahwa hak dan kepentingan tergugat/para tergugat harus sama sekali diabaikan oleh hakim yang menyidangkan perkaranya.

\footnotetext{
${ }^{56}$ M. Yahya Harahap, Op Cit. hlm. 398.

${ }^{57}$ Ibid. hlm. 34
}

$$
\text { Pasal } 125 \text { ayat (1) HIR }
$$
menyebutkan bahwa gugatan itu diterima jika gugatan penggugat tidak melawan hak dan memiliki alasan yang dibenarkan oleh hukum, sehingga ada kewajiban bagi hakim untuk mempertimbangkan tentang ada atau tidaknya hal yang dianggap melawan hak dalam gugatan tersebut. Suatu gugatan dinyatakan ditolak jika penggugat tidak mampu membuktikan dalil-dalil gugatannya atau setidaktidaknya tidak memenuhi batas minimal pembuktian, ${ }^{58}$ ketentuan tersebut berlaku jika hakim berpendapat bahwa dalam acara verstek tetap memerlukan proses pembuktian terhadap dalil-dalil di dalam pokok perkaranya.

Dalam hal suatu gugatan ditolak, maka upaya hukum yang dapat dilakukan oleh penggugat adalah banding ke pengadilan tinggi berdasarkan ketentuan Pasal 6 UU No. 20 Tahun 1947.59

Penolakan atas gugatan penggugat menghilangkan hak penggugat untuk mengajukan kembali perkara itu untuk kedua kalinya. Penolakan gugatan merupakan keputusan yang bersifat positif, sehingga apabila putusan berkekuatan hukum tetap, pada putusan melekat ne bis in idem berdasrkan Pasal 1917 KUH Perdata. Oleh karena itu, apabila penggugat keberatan terhadap putusan, tindakan yang dapat dilakukannya adalah mengajukan upaya banding dan kasasi. 60

58 Abdulkadir Muhammad, Hukum Acara Perdata Indonesia. (Citra Aditya Bhakti; Bandung, 1992). hlm. 100.

${ }^{59}$ D.Y. Witanto, Op Cit. hlm. 137.

${ }^{60}$ M. Yahya Harahap. Op Cit. hlm. 399. 
C. Putusan Verstek yang Menyatakan Gugatan Tidak Dapat Diterima

Kalimat terakhir Pasal 125 ayat (1) HIR menegaskan: kecuali nyata kepada pengadilan negeri, gugatan melawan hukum atau tidak beralasan. Memperhatikan ketentuan di atas, hakim harus menyatakan gugatan tidak dapat diterima apabila gugatan: 61

1. Melawan hukum atau ketertiban dan kesusilaan (unlawful) ;

2. Tidak beralasan atau tidak mempunyai dasar hukum.

Misalnya, dalil gugatan bertitik tolak dari perjanjian yang mengandung kuasa yang haram (ongeoorloofde oorzaak). Atau gugatan berdasarkan $\mathrm{PMH}$ terhadap tergugat, karena tergugat melaporkan penggugat kepada kepolisian. Dalam contoh di atas, gugatan yang diajukan bertentangan dengan hukum dan tidak memiliki dasar alasan yang sah. Tidak layak dan tidak adil untuk dikabulkan. Tindakan yang objektif dan rasional diambil hakim terhadap gugatan seperti itu adalah menyatakan gugatan tidak dapat diterima. ${ }^{62}$

Gugatan dinyatakan tidak dapat diterima (niet ontvankelijk verklaard) pada umumnya disebabkan karena gugatan tersebut memiliki cacat formil maupun cacat materiil. ${ }^{63}$ Ada beberapa keadaan yang menyebabkan suatu gugatan menjadi cacat formil, antara lain sebagai berikut :

1. Materi sengketa bukan merupakan kompetensi secara absolut dari pengadilan negeri yang memeriksa

\footnotetext{
${ }^{61}$ Ibid. hlm. 398.

${ }^{62}$ Soepomo, Hukum Acara Perdata Pengadilan Negeri. (Pradnya Paramita; Jakarta, 1993). hlm. 34.

${ }^{63}$ D.Y. Witanto, Op Cit. hlm. 138.
}

perkara tersebut, sehingga pengadilan negeri tidak berwenang mengadili perkara tersebut secara absolut ;

2. Gugatan telah diajukan pada pengadilan negeri yang tidak berwenang mengadilinya secara relatif ;

3. Gugatan diajukan oleh seorang kuasa yang tidak sah atau tidak mendapatkan kuasa secara khusus dari pihak prinsipal ;

4. Gugatan yang diajukan mengandung kekeliruan di dalam penentuan subjek tergugat ;

5. Gugatan yang diajukan mengandung kekurangan pihak ;

6. Gugatan yang diajukan oleh orang yang tidak berwenang mengajukan gugatan itu, misalnya gugatan tentang warisan padahal ia sendiri bukan sebagai ahli waris;

7. Gugatan mengandung alamat terugat yang salah atau tidak jelas domisilinya.

Sedangkan suatu gugatan dianggap mengandung cacat materiil, antara lain:

1. Rumusan gugatan yang diajukan tidak memiliki korelasi antara posita dengan petitumnya ;

2. Gugatan mengandung objek gugatan barang tetap yang tidak jelas, baik letak, luas, dan batas-batasnya ;

3. Gugatan tidak jelas apa yang didalilkan dan apa yang dituntutnya (obscuur libels) ;

4. Gugatan tidak mencantumkan objek gugatan yang jelas dan pasti berdasarkan ciri dan kriteria objek gugatan tersebut;

5. Gugatan yang diajukan mengandung materi ne bis in idem ; 
6. Gugatan yang diajukan telah daluwarsa (verjaring) ;

7. Gugatan mengandung persoalan exceptio non adimplenti contractus.

Jika putusan menyatakan bahwa gugatan penggugat tidak dapat diterima, maka pokok perkara dalam gugatan tersebut sebenarnya belum sempat diadili. Upaya hukum bagi putusan yang menyatakan gugatan tidak dapat dietrima adalah banding, namun jika memang alasan dalam putusan tersebut cukup kuat, sehingga akan menjadi sia-sia jika penggugat tetap mengajukan banding, maka biasanya penggugat lebih memilih untuk memperbaiki dan memasukkan kembali gugatan itu setelah yang menjadi alasan gugatan itu tidak dapat diterima diperbaiki terlebih dahulu, kecuali jika alasan yang mendasar itu bersifat mutlak dan tidak mungkin untuk diperbaiki.

Putusan yang menyatakan gugatan tidak dapat diterima (niet ontvankelijk verklaard) tidak mengandung ne bis in idem sehingga penggugat memiliki kesempatan untuk mengajukannya kembali, namun walaupun demikian terhadap alasan-alasan tertentu misalnya karena penggugat bukan orang yang berhak mengajukan gugatan atau karena gugatan tersebut telah daluwarsa (verjaring) atau perkara yang diajukan pernah diputus oleh pengadilan yang telah berkekuatan hukum tetap, maka terhadap putusan yang menyatakan gugatan tidak dapat diterima $(N O)$ dengan alasan-alasan seperti itu tidak dapat diajukan lagi dan jika penggugat tetap mengajukan kembali gugatannya, pada akhirnya tetap akan dinyatakan tidak dapat diterima.

\section{SIMPULAN}

Berdasarkan Pasal 125 ayat (1) HIR dan Pasal 149 R.Bg yang berbunyi bahwa "Jika pada hari yang telah ditentukan tergugat yang telah dipanggil dengan patut, tidak menghadap dan tidak pula menyuruh orang lain menghadap untuknya, maka gugatan dikabulkan dengan verstek, kecuali jika Pengadilan Negeri berpendapat bahwa gugatan itu melawan hukum atau tidak beralasan."

Dalam proses persidangan di depan Pengadilan Negeri dikenal adanya putusan akhir sebagai putusan yang berfungsi untuk mengakhiri sengketa atau perkara. Putusan verstek sebagai putusan hakim Pengadilan Negeri dalam perkara perdata adalah salah satu putusan yang masuk dalam golongan putusan akhir. Dalam hukum acara perdata Indonesia mengenai putusan verstek ini diatur dalam pasal 125 H.I.R/149R.Bg. ketidakhadiran para pihak tergugat pada hari sidang yang telah ditentukan adalah salah satu syarat untuk bisa dijatuhkannya putusan verstek oleh hakim Pergadilan Negeri yang memimpin sidang dalam perkara perdata.

\section{DAFTAR PUSTAKA}

Dewi, Gemala. 2005. Hukum Acara Perdata Peradilan Agama di Indonesia. Jakarta: Kencana

Engelbrecht. 2007. Himpunan Peraturan Perundang-Undangan Menurut Sistem Engelbrecht, Buku I, Tata Negara, Perdata, Dagang, Pidana. Jakarta: Ichtiar Baru Van Hoeve

Karjadi, M. 1991. Reglemen Indonesia yang Diperbaharui, S 1941 No. 44, RIB (HIR) Bogor: Politeia

Keputusan Ketua Mahkamah Agung Republik Indonesia Nomor : KMA/032/SK/IV/2006 angka ke-2 huruf $\mathrm{C}$.

Mertokusumo, Sudikno. 1988. Hukum Acara Perdata Indonesia, cet.ke-III. Yogyakarta: Liberty

Mertokusumo, Sudikno. 2002. Hukum Acara Perdata. Yogyakarta: Liberty 
Muhammad, Abdulkadir. 2000. Hukum Acara Perdata Indonesia. Bandung: Citra Aditya Bakti

Puspa, Yan Pramadya. 1977. Kamus Hukum, Edisi Lengkap, Bahasa Belanda Indonesia Inggris. Semarang: Aneka Ilmu

D.Y, SH. 2013. Hukum Acara Perdata Tentang Ketidakhadiran Para Pihak Dalam Proses Berperkara. Bandung: Mandar Maju.

R, Soeroso, SH. 2011. Hukum Acara Perdata HIR, Rbg, dan Yurisprudensi. Jakarta: Sinar Grafika

R. Supomo. 1980. Hukum Acara Perdata Pengadilan Negeri. Jakarta: Pradnya Paradita

Saleh, K. Wantjik. 1977. Hukum Acara Perdata. Jakarta: Ghalia Indonesia

Soesilo. 1985. RIB/HIR dengan Penjelasan. Bogor: Politeia

Soepomo. 1993. Hukum Acara Perdata Pengadilan Negeri. Jakarta: Pradnya

Subakti. 1977. Hukum Acara Perdata. Jakarta: Bina Cipta

Varia Peradilan Majalah Hukum Tahun XXIX No. 338 Januari 2014

Wulan Sutantio, Retno dan Iskandar Oeripkartawinata. 2002. Hukum Acara Perdata Dalam Teori dan Praktek. Bandung; Mandar Maju

Yahya, M Harahap SH. 2006. Hukum Acara Perdata. Jakarta: Sinar Grafika

Yahya Harahap. 2005 Hukum Acara Perdata, Tentang Gugatan, Persidangan, Penyitaan, Pembuktian, dan Putusan Pengadilan. Jakarta: Sinar Grafika

Zuhriah, Erfaniah. 2008. Peradilan Agama di Indonesia. Malang: UIN-Malang Press

KUH Perdata

KUHAPerdata

HIR dan R.Bg 